\title{
TESTING, GAUGING AND LIFTING CURVES CHARACTERISTIC OF CURRENT TRANSFORMERS AND PROTECTION RELAYS
}

\author{
U. Moreira ${ }^{1}$, M. R. Castillo ${ }^{1}$, L. Brito ${ }^{1}$, F. A. Moura ${ }^{1}$, M. V.Mendonça ${ }^{1}$, A.J. \\ Rosentino $^{1}$, D. Rodrigues ${ }^{1,}$ R. Rimoldi de Lima ${ }^{1}$, P. H. Rezende, , G. Lima ${ }^{2}$ and J. O. \\ Rezende ${ }^{3}$, \\ ${ }^{1}$ Department of Electrical Engineering \\ Triangulo Mineiro Federal University ${ }^{2}$ Department of Electrical Engineering \\ Federal University of Uberlandia, ${ }^{3}$ Department of Electrical Engineering \\ of Federal Institute of Goias. \\ Campus of Unit II ICTE Av. Randolfo 1378, Uberaba, MG (Brazil) \\ Phone/Fax number:+0034 997932329, e-mail: madeleine.albertini@uftm.edu.br
}

\begin{abstract}
The main purpose of working with the techniques of testing, lifting curves for current transformers (TC) and measurement of protection relays, is to ensure the safe and effective operation of electrical power systems, not only on a permanent basis, but also in contingency situations. In view of this, this document presents the theoretical foundations regarding the principle of operation of TCs and relays aiming at further technical clarification of these equipments. In addition, the main national and international standards for the specifications of the TCs and for the criteria for approval in commissioning tests are addressed. Furthermore, we discuss the requirements and procedures for the testing of TCs combined with an in-depth study of the functions 50/51 (Overcurrent) and 87 (Differential) of the SIPROTEC 7UT relay. Finally, at the end of this document, the set of tests applied in the TCs and relays for the functions mentioned above is presented.
\end{abstract}

Keywords - Current Transformer, Commissioning Tests, Relays, Function 50/51 (Overcurrent), Function 87 (Differential).

\section{INTRODUCTION}

The Brazilian electricity transmission system is highly interconnected and tends to expand interconnect, which brings numerous advantages for consumers, such as reliability, continuity, safety and economy. However, to achieve the desired reliability, it is necessary that each of the components of this system function properly, in order to prevent the collapse, and may generate blackouts on a national scale, as seen in October 2012, which affected a large part of states of the North and Northeast regions $[1,2]$. The size of the system is directly related to its complexity. Thus, with the interconnection characteristic of the Brazilian system, it is impossible for it to be immune to the disturbances that occur frequently, which may result in interruptions in supply and damage to the components that compose it. Given these conditions, protection must be planned in order to receive the information of electrical $i$. quantities in real time, to efficiently carry out the decisionmaking for which it is responsible, since the main function of the protection is to ensure the disconnection of the portion of the electrical system subjected to any abnormality that makes it operate outside or part of the intended limits [3].
Therefore, to ensure a proper functioning of the system as a whole, protective equipment such as circuit breakers, TCs, potential transformers (TP) and relays are used. These are responsible for avoiding system failures, which can damage equipment, promoting the rapid restoration of energy, avoiding damage to consumers and providing better quality in the supply of energy to users.

In order for these equipments to fill in their role, that is, to deliver the correct information, acting satisfactorily within their protection zone, they are subjected to tests and tests.

In view of the above, this work aims to present the test procedures and tests in TCs and digital relays, aiming to provide access to information and laboratory testing methodology. In addition, this work will present the main normalizations applied in this area, empirically demonstrating the main tests and their ways of measuring these equipments, before they are integrated into the electrical networks.

\section{METHODOLOGY APPLICATION}

\section{Equipment for TC}

The CE-7012 equipment was used to perform the tests. This equipment is very useful due to its versatility and numerous features for testing and analysis of the electrical system. In addition, it is a portable instrument, and can be used in field or laboratory tests, allowing tests, calibration and measurement of the most diverse types of equipment at primary and secondary levels.

At primary levels, it can be used for testing on TCs, TPs, disconnectswitches, circuit breakers, among others. At secondary levels, it allows testing in electromechanical, static or microprocessed relays. In addition, due to the high accuracy of the signals generated, it is widely used for measuring transducers and.

\section{Current Transformer}

TCs are equipment that have as primary function to feed measuring, control and protection equipment at appropriate levels, because in SEPs, the quantities such as voltage and current have high values. In this way, the TC is used to read the electric current at a certain point in the system and, thus, 
this information is transmitted to the protective, measuring and control equipment.

In summary, the TC resembles a TP, being endowed with a primary winding connected in series, in order to reproduce in the secondary, under normal operating conditions, a current proportional to that of the primary, with the angular position of the fasor substantially maintained.

Serial connection therefore occurs the current that the TC should read is the current that circulates in the specified branch. In the secondary, the loads are also associated in series, so that you have a single chain for all equipment installed in this winding. [4,5]

The specifications of the TC used are shown in Figure 1. For this work, the TC was used in the connection that presents a transformation ratio of 1200 - 5th.

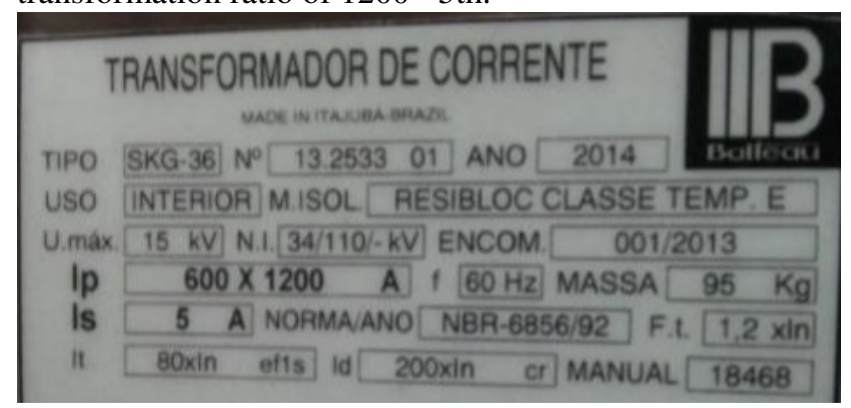

Fig. 1. TC plate data studied.

\subsection{Magnetization Curve}

The current in the TC primary is responsible for generating a magnetic flow that circulates through the core and ties the secondary coils, promoting the current circulation in the same.

Thus, as the quantities present in the TC primary increase, there is a corresponding increase in the secondary voltage, due to the increase in magnetic flux. Therefore, there is a greater possibility of saturation [11].

This is due to the flow generated by the excitation current, which is responsible for the reading error in a TC, and that during saturation, presents a very sharp value, since the core is overloaded and requires greater current for maintenance circulating flow.

Therefore, it is necessary to have a greater knowledge about the excitation current, seeking to ensure that the TC does not saturate and thus does not interfere in the correct operation of the protection system. For this, some tests are carried out in order to survey this current.

Thus, with the primary open, a voltage level is injected into the TC secondary and its current is measured until a small increase in voltage generates a large current variation, as illustrated in Figure 2.

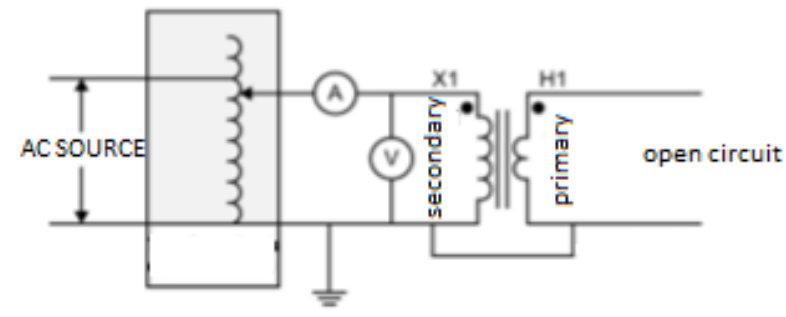

Fig. 2. Test for lifting the saturation curve.

The test is performed in the secondary, due to the small current value that needs to be applied, since this winding works with a higher voltage level. This situation is preferable, because the limiting factor for this case is the insulation of the equipment, which does not change its size. $[12,13]$.

\subsection{Winding resistance}

At this stage, we seek to measure the resistance of the TC winding to compare with the manufacturer's values, and thus verify that there was no damage to the equipment during transportation. In addition, this test may indicate the existence of short-circuited turns and connections and contacts in poor conditions $[14,15]$.

There are several methods to perform this test, the types are chosen according to the desired accuracy, as shown in table 1 .

Table 1. Order of magnitude of Ohmic resistance for choice of measurement method.

\begin{tabular}{|l|l|l|}
\hline Order of mag. & \multicolumn{2}{|l|}{ Measurement method } \\
\hline$<0,001$ & Voltage drop & $\begin{array}{l}\text { MICRO } \\
\text { Ohmímetro }\end{array}$ \\
\cline { 1 - 2 } Between 0,000001 and 1 & Bridge Kelvin & Digital \\
\hline$>1$ & Bridge Wheatston & Dign \\
\hline
\end{tabular}

\subsection{Voltage Method}

In summary, this method consists of reading an $\mathrm{R}$ resistance of the winding, traversed by a current $\mathrm{I}$ that causes a voltage drop $\mathrm{V}$ on the resistance analyzed in the test. That is, a DC voltage is applied to the terminals of a winding and the current readings circulating in the measured winding and the voltage drop between its terminals are performed. The value of the winding resistance is obtained through the Ohm Law. It is necessary that the voltmeter is close to the winding terminals and that it is independent of the connection conductors, so that there is no effect of the resistance of the current conductors and their contacts on the resistance of the winding.

For a more accurate result, it is assumed that the current to be applied may not exceed $15 \%$ of the nominal current of the winding under test, in order to avoid overheating of the equipment.

\subsection{Bridge method}

Universal bridges, when used for resistance measurement, have their operating principle based on the Wheatstone bridge, which is a circuit used as a meter by comparison. In its adjustment, the bridge uses the concept of zero detection which is a less sensitive criterion to calibration or precision problems of reference standards.

Therefore, for the performance of this test, $\mathrm{Rx}, \mathrm{Rd}, \mathrm{R} 1$ and $\mathrm{R} 2$ are assumed, where $\mathrm{R} 1$ and $\mathrm{R} 2$ are fixed and known values, $\mathrm{Rd}$ presents variable and known value, and $\mathrm{Rx}$ is the resistance to be determined. Thus, the circuit is fed and the $\mathrm{Rd}$ value is varied to the equilibrium point and then the $\mathrm{Rx}$ value is found through the relationship between the resistances. 


\subsection{Correction of resistance as a function of temperature}

For this test, the TEMPERATURE of the TC must be stabilized so that the values obtained can be correctly corrected to a common basis.

The resistance values found must be corrected according to the manufacturer's reference temperature (Ts), usually $75^{\circ} \mathrm{C}$, using equation 1 .

$$
R s=R t \cdot \frac{T s+K}{T+K}
$$

Where:

Rs - Winding resistance, corrected to reference temperature, in Ohms;

$\mathrm{Rt}$ - Winding resistance obtained in the test, in Ohms;

$\mathrm{T}$ - Winding temperature at resistance measurement;

$\mathrm{K}$ - Winding material feature constant.

Obs: For pure copper $100 \%, \mathrm{~K}=234,5$

For copper to the $97,3 \%, \mathrm{~K}=242$.

\subsection{Transformation ratio}

The transformation relationship is the relationship between the induced stress in the primary and the induced stress in the secondary, so this test is of great importance, since it allows analyzing the state of the transformer windings, that is, it allows us to know if there is a short between turns or even if the windings are open.

According to the literature, this analysis can be performed in two ways: by the voltage method or by the current method [16].

For the realization of the first, a voltage level AC is applied and a transformer with variable spin numbers is connected to the secondary terminals. So, we read the voltage presented in the primary.

The stress value found in the primary should be lower than the voltage applied to the secondary, since the transformation ratio is inverse between currents and stresses $[5,16]$.

Figure 3 shows the connection scheme for performing the voltage method.

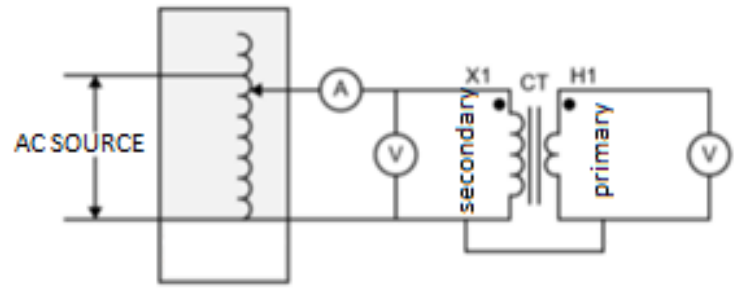

Fig. 3. Voltage method.

For the current method, the behavior of the TC in normal operation is analyzed. To do this, a nominal current is applied to the primary and the current value of the secondary. A load transformer is used, which behaves as a voltagecontrolled current source. This is connected to an AC source through a transformer with variable turns. A reference TC is also used, which is connected in series to the TC in test. In addition, current meters are connected on the secondary of both TCs.

Figure 4 demonstrates the current method.

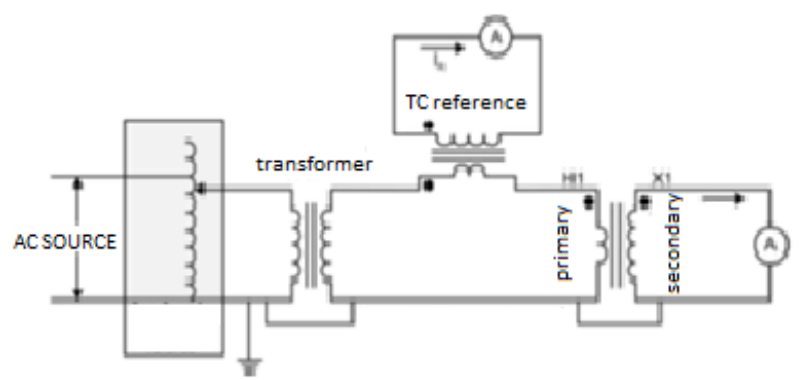

Fig. 4. Current Method.

The known reason TC is the reference TC and is connected in series to the test TC primary circuit. The ratio of TC under assay is demonstrated in equation 2 .

$$
N t=N_{R} \cdot \frac{I_{R}}{I t}
$$

Where:

$\mathrm{Nt}$ - Relationship of TC subject to assay;

$\mathrm{Nr}$ - Reference TC ratio;

Ir - Corrente secundária do TC de referência;

It - Secondary TC current under assay.

\section{Tests Equipment for Relays}

The CE-6006 was used for the relay tests. This is a hexaphasic equipment built for testing the electrical protection system. Because it is portable, it allows testing, calibrating and measuring the most diverse types of relays, transducers and qualimeters.

As for electromechanical relays, the CE-6006 provides high power for high impedance testing without the need for additional hardware.

\section{Protection Relay}

Relays applied to SEPs have the primary function of identifying and locating faults with the lowest possible error rate. In addition, it should alert the system operator if failures occur and command the performance of protective devices, such as circuit breakers, in order to isolate the defect.

Therefore, relays act as sensors, constantly analyzing the operation of the network, and if any disturbance occurs, they are triggered [4].

Relays, over time, have evolved, however, the philosophy of protection remains the same [11]. With this, they must act according to some criteria, such as sensitivity, selectivity and reliability.

Although the goal of the protection is always the same, it is necessary specific relays for each type of equipment. The most relevant for this study are the overcurrent relay and the differential relay.

The overcurrent relay (50/51) acts when passing through it, a current of value greater than its adjustment value. It is an essential protection in all segments of the electrical system. The differential relay, on the other hand, has as a principle, to compare the input current with the output current of a given equipment. Thus, if the current value found during the 
comparison is greater than the relay setting current, it will fire by opening the circuit breaker.

In general, it can be observed that relays are responsible for the logic of action, that is, through the information that is sent to their coils, through TCs or TPs, they decide whether or not to send an opening signal for the performance of a circuit breaker [12, 13, 14].

\section{Digital Relays}

Digital relays are increasingly occupying a place of importance in protection systems because, in addition to offering the same characteristics as their predecessors, they can also provide other functions, such as data storage by example, that due to the fact that its memory is not volatile, ensures that even if the relay is deenergized, it is able to keep the data stored for a long time. In addition, they allow remote access, have greater speed in failure responses and are threephase [12,13].

Another very significant advantage of digital relays is that they are protections based on microprocessed techniques, that is, all the logic of operation of relays is made through algorithms that interpret input quantities and make some kind of decision. Because of this, a single equipment, can contain numerous features, that is, a digital relay may be able to perform the functions of overcurrent relays, directional, distance and differential [12].

\section{PRESENTATION OF RESULTS}

\section{Tests on TCs}

\subsection{Magnetization Curve}

For the $\mathrm{cm}$ survey, the tc secondary feeding was limited to an application of $900 \mathrm{~V}$ and $1 \mathrm{~A}$.

Figure 5 shows the result obtained by this assay, which shows that the raised $\mathrm{CM}$ is within the range established by NBR 6856 . In addition, the knee point is given by voltage, which in the face of a $10 \%$ increase, results in a $50 \%$ increase in current.

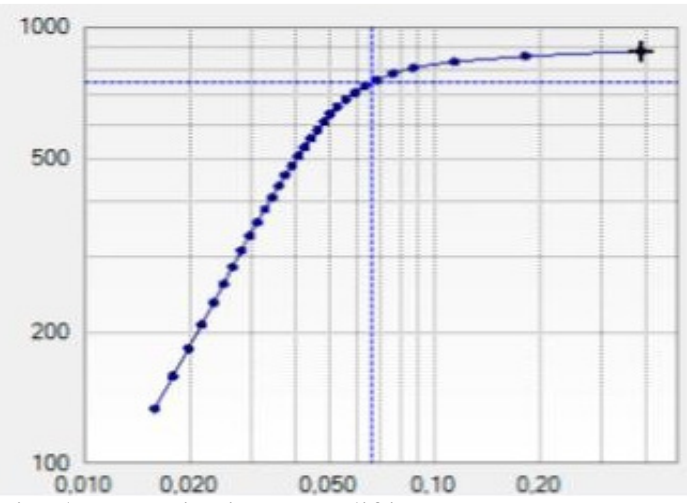

Fig. 5. Magnetization curve lifting.

\subsection{Winding Resistance}

To measure the winding resistance by means of the equipment, the ambient temperature at the time of testing was set in the software. The time has been set to $10 \mathrm{~s}$, which is a considerable time for winding resistance to undergo variations.

The adjusted parameters are displayed in Figure 6.

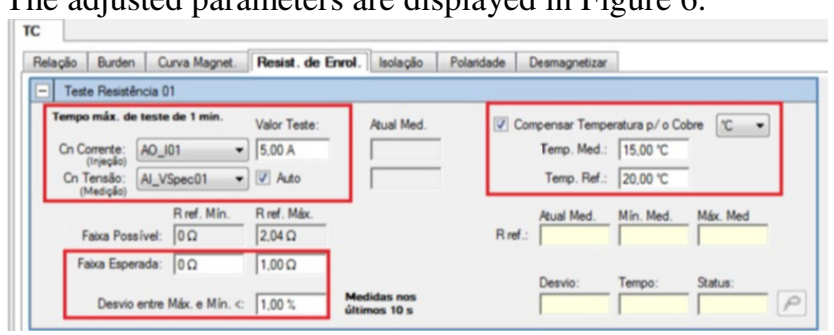

Fig. 6. Adjustments for winding resistance test.

After parameterization and connection of the test bag to ct, the assay was performed and the results were obtained. These results can be seen in Figure 7.

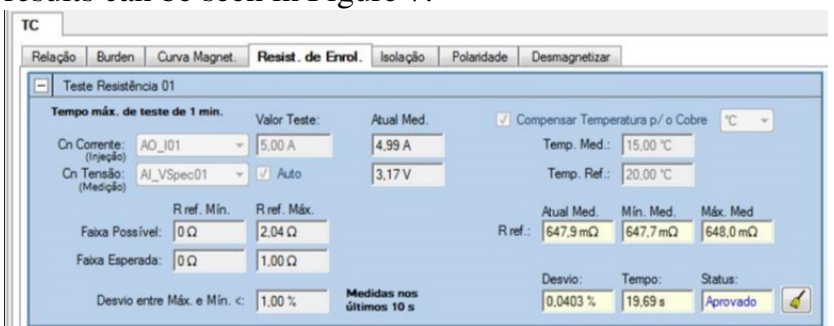

Fig. 7. Test results.

According to NBR 6856, the values obtained in this test must be equal to or lower than the limit values provided by the manufacturer [6]. Therefore, it is concluded that the response obtained is within the expected range of.

\subsection{Transformation Relationship}

First, the TC was defined, respecting its class of accuracy, which is $10 \%$, as low reactance and with maximum voltage in the secondary of $800 \mathrm{~V}$, for a short circuit situation and that the error tolerance is $10 \%$.

Thus, the software was parameterized with the plate data and tolerance, as shown in Figure 8.

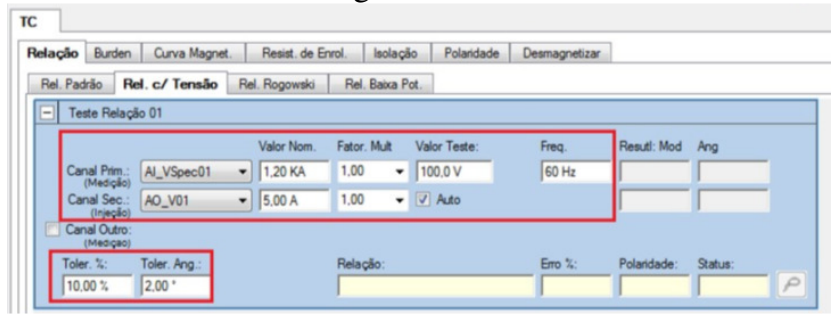

Fig. 8. Parameterization of software for Transformation Relationship testing.

The results are shown in Figure 9.

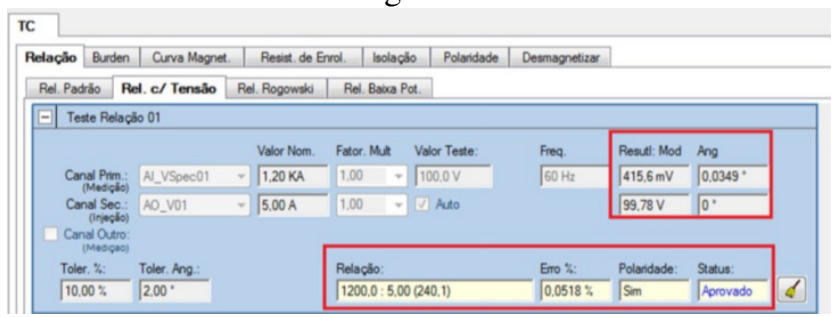

Fig. 9. Transformation relationship test results. 


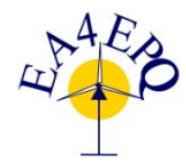

$18^{\text {th }}$ International Conference on Renewable Energies and Power Quality (ICREPQ’20)

Granada (Spain), $1^{\text {st }}$ to $2^{\text {nd }}$ April 2020

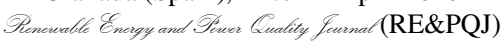

ISSN 2172-038 X, Volume No.18, June 2020

In view of the results, it is observed that the transformation ratio presents a small error and lower than the $10 \%$ guaranteed by the manufacturer in the face of a short circuit situation.

This response was expected, as the error rate is related to the rated current.

\section{Tests in Relays}

\subsection{Differential Function}

To measure the operation of the SIPROTEC 7UT relay with the differential function, 3 tests are required: configuration test, firing test and search.

The first is necessary to ensure that all parameters are correct, reducing the possibility of failures. The second test evaluates the operation of the relay and its firing time. While the search test, aims to find the pick-up region to define whether it conforms to what has been parameterized.

To adjust the software, you need to know the equipment that must be protected. In this case, the TP, the system TCs and their connection. Tables 3 and 4 show the transformer characteristics of $50 \mathrm{MVA}$ and TCs respectively.

Table 3: Transformer Data

\begin{tabular}{|c|c|c|c|c|}
\hline Winding & Voltage $(\mathrm{KV})$ & Connection & Vector Group & Grounded \\
\hline 1 & 138,00 & $\mathrm{D}$ & - & - \\
\hline 2 & 69,00 & $\mathrm{Y}$ & $1\left(30^{\circ}\right)$ & No \\
\hline
\end{tabular}

Table 4: TC Dtata

\begin{tabular}{|c|c|c|c|}
\hline Winding & Primary Current & Secondary Current & Connection \\
\hline 1 & $250,00 \mathrm{~A}$ & $1,00 \mathrm{~A}$ & Ybar \\
\hline 2 & $500,00 \mathrm{~A}$ & $1,00 \mathrm{~A}$ & Ybar \\
\hline
\end{tabular}

The adjustments for the relay can be found in Tables 5 to 7 :

Table 5: Pick-up Adjustments

\begin{tabular}{|c|c|c|}
\cline { 2 - 3 } \multicolumn{1}{c|}{} & Percentage Adjustment & Instant Adjustment \\
\hline Pickup & $0,23 \mathrm{In}$ & $6,00 \mathrm{In}$ \\
\hline Time & $0,00 \mathrm{~s}$ & $0,00 \mathrm{~s}$ \\
\hline
\end{tabular}

Table 6: Tolerances for differential function

\begin{tabular}{|c|c|c|}
\cline { 2 - 3 } \multicolumn{1}{c|}{} & Tolerance & Absolute Tolerance \\
\hline Range & $5,00 \%$ & $0,01 \mathrm{~A}$ \\
\hline Time & $1,00 \%$ & $0,03 \mathrm{~s}$ \\
\hline Angle & - & $3,00^{\circ}$ \\
\hline
\end{tabular}

Table 7: Slope Configuration

\begin{tabular}{|c|c|c|c|}
\hline Slope 1 & Base point 1 & Slope 2 & Base point 2 \\
\hline $30,00 \%$ & 0,00 & 50,00 & 3,5 \\
\hline
\end{tabular}

\subsubsection{Shooting Test}

As the configuration test showed that the parameters were adjusted correctly, the relay is tested. For this, the test points were selected as shown in Figure 10. It is noteworthy that points should not be selected in the region of uncertainty, which is represented by the region in blue.

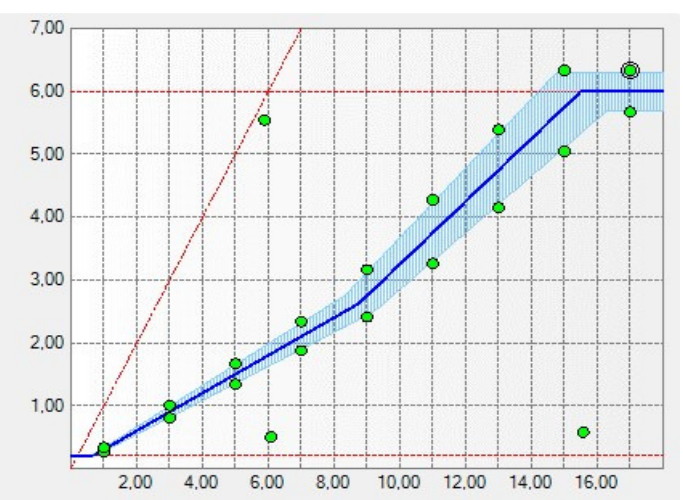

Fig.10. Test chart Source: From the author, 2019.

For the selected points, table 8 obtained the status of the relay for a fault A-B-C in winding 02, approved or disapproved, as well as the time of operation of the relay. In order to synthesize the table and knowing that it would not compromise its understanding, the values from 1 to 6 were presented.

Table 8: Shooting Test Result

\begin{tabular}{|c|c|c|c|c|c|c|c|}
\hline Pto & IRest & IDif & Reg & Acted & $\begin{array}{c}\text { tOp } \\
\text { Nom }\end{array}$ & tOp Real & Status \\
\hline 01 & 6,08 In & 0,500 In & NOp. & No & - & - & Ap \\
\hline 02 & 15,57 In & 0,578 In & NOp. & No & - & - & Ap \\
\hline 03 & 5,88 In & 5,55 In & Op. & Yes & 0 s & $25,80 \mathrm{~ms}$ & Ap \\
\hline 04 & 1,00 In & $267,9 \mathrm{~m}$ In & NOp. & No & - & - & Ap \\
\hline 05 & 1,00 In & $333,9 \mathrm{~m}$ In & Op. & Yes & 0 s & $28,02 \mathrm{~ms}$ & Ap \\
\hline 06 & 3,00 In & 0,804 In & NOp. & No & - & - & Ap \\
\hline
\end{tabular}

For all points exposed, the relay approval is observed, as it is within the tolerances provided by the manufacturer, as shown in Table 8. Thus, in the case of the operating regions and the firing times, the relay performance was acceptable.

\subsubsection{Search Test}

The search test aims to find the point at which the relay is sensitized, that is, when it reaches the pick-up. This analysis confirms whether the characteristics of the relay curves are in accordance with the parameterized.

The results of this test are shown in Figure 11, which shows which points were found by the software through the lines.

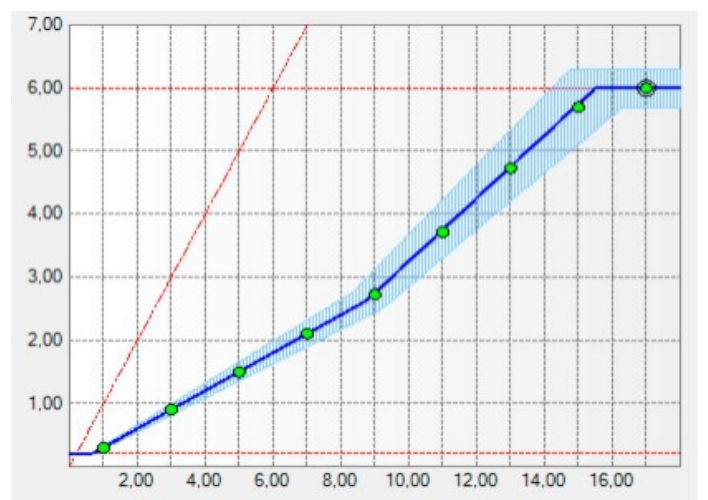

Fig.11. Test result. 
Table 9 was obtained with the selection of points, which exposes the results of the search test with the indication of approval or failure. As in table 8, because it did not compromise the understanding of the results, the table was formed with points 1 to 6 .

Table 9: Search test result

\begin{tabular}{|c|c|c|c|c|c|c|}
\hline Pto & Falta & Local & IRest & IDif Nom & IDif Real & Status \\
\hline 01 & A-B-C & Enr. 02 & $1,00 \mathrm{In}$ & $300,0 \mathrm{~m}$ In & $295,5 \mathrm{~m} \mathrm{In}$ & $\mathrm{Ap}$ \\
\hline 02 & A-B-C & Enr. 02 & $3,00 \mathrm{In}$ & $0,900 \mathrm{In}$ & $0,900 \mathrm{In}$ & $\mathrm{Ap}$ \\
\hline 03 & A-B-C & Enr. 02 & $5,00 \mathrm{In}$ & $1,50 \mathrm{In}$ & $1,49 \mathrm{In}$ & $\mathrm{Ap}$ \\
\hline 04 & A-B-C & Enr. 02 & $7,00 \mathrm{In}$ & $2,10 \mathrm{In}$ & $2,10 \mathrm{In}$ & $\mathrm{Ap}$ \\
\hline 05 & A-B-C & Enr. 02 & $9,00 \mathrm{In}$ & $2,75 \mathrm{In}$ & $2,72 \mathrm{In}$ & $\mathrm{Ap}$ \\
\hline 06 & A-B-C & Enr. 02 & $11,00 \mathrm{In}$ & $3,75 \mathrm{In}$ & $3,71 \mathrm{In}$ & $\mathrm{Ap}$ \\
\hline
\end{tabular}

In view of the above, it can be concluded that the relay for the differential function is approved, because the results are within the tolerance range.

\section{CONCLUSION}

This paper presented the main fundamentals on TCs and protection relays, highlighting the overcurrent and differential functions. In addition, it covered in detail the main tests that are performed for the approval of the equipment before placing them in the field. Such tests are of great importance to ensure the good performance of the equipment, since they operate in the SEP and therefore, their poor performance can lead to numerous setbacks for customers and for the energy concessionaire itself.

Thus, the equipment used for these tests was presented and it was proved that, due to the high technology employed, the processes were automated, which allows faster analysis.

Through the above, it is expected to have contributed to those who study the SEPs, showing the importance of performing commissioning tests on protective equipment and performing routine tests, which aim to maintain the integrity of the equipment, ensuring the quality of preventive and predictive maintenance.

\section{REFERENCES}

[1] “Apagão afeta o Nordeste do país” - Portal de Notícias G1. Disponível http://g1.globo.com/brasil/noticia/2012/10/apagaoatinge-o-nordeste-do-pais.html. Acessado em fevereiro de 2019.

[2] MONOGRAFIAS.POLI.UFRJ.BR. Sistemas de proteção, controle e supervisão em subestações de energia elétrica: uma visão geral. Disponivel em:<http://monografias.poli.ufrj.br/monografias/monopoli100 08656.pdf>. Acesso em: 17 fev. 2019.

[3] UNIVERSIDADE SÃO FRANCISCO. Sistema de proteção da rede de distribuição de energia elétrica. Disponível em: <http://lyceumonline.usf.edu.br/salavirtual/documentos/2587.pdf>. Acesso em: 17 fev. 2019.

[4] Kindermann, G. Proteção de Sistemas Elétricos de Potência. Edição do Autor - Florianópolis - SC, 2005, $2^{a}$ edição.

[5] SPPEZAPRIA, F.B da R, Métodos de Ensaio Aplicados na Manutenção de Transformadores de Corrente de Alta Tensão. Trabalho de Conclusão de Curso. Universidade Federal da Paraíba, 2017.

[6] ABNT NBR 6856 - Transformador de Corrente. 2015

[7] CARDOSO,A.J da.R. Ensaios das Funções de Sobrecorrente e Distância utilizando Relé Digital de Proteção e Aplicação de Sinais com Caixa de Teste. Trabalho de Conclusão de Curso. Universidade Federal do Pampa, 2018.

[8] FILHO, João Mamede; MAMEDE, Daniel Ribeiro. Proteção de Sistemas Elétricos de Potência. Rio de janeiro: LTC, 2011.

[9] PRUDÊNCIO, G.M.R. Análise de Relés Digitais de Sobrecorrente Utilizando Simulação Computacional. Trabalho de Conclusão de Curso. Universidade Federal da Paraíba, 2016.

[10] Kindermann, G. Proteção de Sistemas Elétricos de Potência. Volume 2. Edição do Autor - Florianópolis - SC.

[11] BERNARDES,A.P. Esquema Completo de Proteção Diferencial de Transformadores para Testes em um Relé Digital. Dissertação de Mestrado. Universidade de São Paulo, 2006.

[12] SILVA, Paulo Sérgio; Investigação sobre os efeitos da saturação em transformadores de corrente de proteção. Programa de Pós-Graduação. Universidade Federal de Minas Gerais, 2014.

[13] CONPROVE TUTORIAIS. Curva de Magnetização. Julho de 2016.

[14] ALVES, J.S. Ensaios e Testes de Comissionamento e de Manutenção em Transformadores e reatores de Potência (Teoria e Práticas). Apostila de Curso Técnico, março de 2018.

[15] JUNIOR, R.C, COMISSIONAMENTO DE TRANSFORMADORES 13,8/500kV DA USINA HIDRELÉTRICA DE TUCURUÍ. Trabalho de Conclusão de Curso. Universidade Federal do Pará, 2015.

[16] IEEE C57.13.1-2017. IEEE Guide for Field Testing of Relaying Current Transformers. Edição 6.12. 2017. 